\title{
Social capital and culture: master keys to development
}

\section{Bernardo Kliksberg}

Coordinator, Inter-American Institute for Social Development (INDES),

Inter-American

Development Bank.
This article explores the potential of social capital and culture for contributing to economic and social development. It centers its attention particularly on the situation of Latin America: a region with serious problems of poverty and lack of equity which affect vast sectors of the population, so that it has been considered the continent with the greatest levels of inequality. It is argued here that although it is true that the integration of the questions of social capital and culture into development discussions makes the search for suitable strategies and designs more complex, it is equally true that policies based on designs which leave out such aspects have proved to suffer from serious limitations. The article first of all explores the general idea of social capital, with emphasis not so much on theoretical analysis as on the concrete presence of such capital in actual situations. It then goes on to examine social capital in action in specific Latin American cases and finally formulates some considerations on the possible contributions of culture to Latin American development. 


\section{I \\ The new development debate}

As the twentieth century draws to a close, mankind has enormous productive forces at its disposal. The technological revolutions under way have substantially altered its potential capacity to generate goods and services, and the simultaneous advances in such fields as informatics, biotechnology, robotics, microelectronics, telecommunications, science of materials and other areas have led to qualitative leaps forward in production possibilities. At the same time, however, 1.3 billion persons cannot meet their most minimum needs and are living in extreme poverty with an income of less than a dollar a day, 3 billion are living in a state of poverty and have to survive on less than two dollars a day, 1.3 billion persons have no drinking water supply, 3 billion lack basic sanitary installations, and 2 billion have no electricity.

Attaining the sought-for goal of economic and social development is more feasible than ever in terms of technology and production potential, yet at the same time this is a far-off objective for vast numbers of people in various continents, including Latin America.

The "global village" that our planet has become, where interrelations between countries and markets are more numerous every day, also seems to be marked by an explosion of complexity, contradictory forms of evolution and heavy doses of uncertainty. Nobel Chemistry Prizewinner Ilya Prigogine has noted that most of the structures in the present world situation are dissipative, open-ended structures whose future evolution is hard to predict and cannot be explained by traditional logic (Prigogine, 1993). Morin (1991), for his part, asserts that rather than "the end of history", forecast by some analysts who consider that with the disappearance of the bipolar world history is likely to become predictable and even boring, the situation we now have before us is that from now on, the name of the future is "uncertainty".

$\square$ The views expressed in this article are the sole responsibility of the author and do not necessarily represent those of the institution of which he is a staff member.
The kind of history now under way is marked by several contradictions. Thus, while the technological knowledge available to us has multiplied our possibilities of dominating nature, mankind is giving rise to enormous ecological imbalances and endangering basic aspects of the ecosystem and its own survival. Although increased production capacity has brought the world product up to over US\$ 25 trillion, social polarization has grown sharply and, according to United Nations reports (UNDP, 1998b), 358 persons have amassed more wealth than the total possessions of $45 \%$ of the world population. The disparities observed extend to the most basic aspects of everyday life. Thus, the rapid advances made in medicine have made possible a considerable increase in life expectancy, but whereas this amounted to 78 years in 1997 in the 26 richest nations, in the 46 poorest countries it was no more than 53 years. The idea of unlimited progress is being replaced by views that place greater emphasis on the likelihood of more complex problems, contradictions and uncertainties.

Within this general context, a vigorous new debate is under way on development models. In a search for more effective paths to follow in a world where the everyday life of vast sectors of the population is marred by acute unsatisfied needs and where it is estimated that one-third of the economically active population is affected by severe problems of unemployment and underemployment, previous assumptions which are not borne out by the facts are being critically reviewed and variables which were previously given little weight are now being incorporated.

In view of the situations described in the preceding paragraphs, we see that the forecasts that the application of conventional economic theories would bring stable economic progress and reduce poverty and inequality in the developing world have not been fulfilled. As a result, highly respected experts are now calling for a profound review of those theories. For example, the 1998 Nobel Economics Prizewinner Amartya Sen questions the development path usually advocated, describing it as a path marked by "blood, sweat and tears" and a development which is not only "cruel" but also highly inefficient (Sen, 
1997b), while Joseph Stiglitz, former head of President Clinton's team of economic advisers, calls for a post-Washington Consensus that will review the instruments of the original Consensus, asserting that the Latin American experience suggests that we should review, remake and expand the assumptions on development economics which we have so far taken for granted (Stiglitz, 1998). James Wolfensohn, President of the World Bank, has declared that without concomitant social development there cannot be satisfactory economic development (Wolfensohn, 1996). Various recent lines of research have concluded that it is essential to get away from economistic-type reductionist approaches and instead incorporate the political, institutional and cultural dimensions into development thinking. Enrique V.
Iglesias, President of the IDB, has expressed the view that development can only be approached in an integral manner: approaches that address only a single aspect simply do not work (Iglesias, 1997a).

This context of vigorous debate on the validity of conventional economic thinking has created a favourable climate for a growing area of analysis on "social capital", one of the main lines of which is a reappraisal of the relations between culture and development.

The present study addresses the relations between social capital and the various dimensions of development, presents some Latin American examples of the mobilization of social capital, and finally explores some of the contributions that culture can make to economic and social development efforts.

\section{II}

\section{Social capital, culture and development}

The World Bank distinguishes four basic forms of capital: i) natural capital, consisting of a country's endowment of natural resources; ii) constructed capital, which is generated by human beings and includes infrastructure, capital goods, financial capital, trade capital, etc.; iii) human capital, which is determined by the levels of nutrition, health and education of the population, and iv) social capital, which is a recent discovery of development sciences. Some studies consider that the last two forms of capital are responsible for most of the economic development of nations in the latter years of the twentieth century and assert that they represent the master keys to technological progress, competitiveness, sustained growth, good government and stable democracy.

What is social capital, in the final analysis? There is as yet no generally accepted definition. This concept has only recently begun to be explored, and its identity is still being defined. In spite of the considerable areas of vagueness, however, there is an increasingly general impression that, as they begin to explore it, the development disciplines are incorporating into their area of knowledge and action a very wide range of important variables which were previously outside the conventional framework.

Robert Putnam -one of the pioneers in the analysis of social capital- said in his well-known study on the dissimilarities between Northern and Southern Italy that such capital consists fundamentally of the degree of confidence that exists between the social actors of a society, the norms of civic behaviour they observe, and the level of associativeness (Putnam, 1994). These elements show the wealth of resources and the strength of the social fabric. Confidence, for example, acts as an element that reduces potential conflicts by limiting the tendency to perceive areas of discord. Positive attitudes in terms of civic behaviour, which range from looking after public spaces to the payment of taxes, contribute to general well-being. The existence of high levels of associativeness in a society shows that it has the capacity to act in a cooperative manner, forming all kinds of networks, concerted arrangements and synergies. In Putnam's view, these factors are more frequent and deep-rooted in Northern Italy than in the South of that country and played a decisive role in the better economic performance, better quality of government and greater political stability of Northern Italy.

James Coleman, another pioneer in this field, considers that social capital exists at both the individual and collective levels. The first of these is connected with an individual's degree of social integration and his network of social contacts: it im- 
plies reliable relations, expectations of reciprocity and forms of behaviour and improves effectiveness at the private level. It is also a collective good, however. Thus, for example, if everyone in a particular neighbourhood shares tacit standards of non-aggression and concern for others, children will be able to walk to school in perfect safety and social capital will be producing public order (Coleman, 1990).

Different analysts stress different aspects. Thus, Newton (1997) considers that social capital may be seen as a subjective phenomenon, made up of values and attitudes that affect the way people relate with each other. It includes confidence, norms on reciprocity, attitudes and values which help people to surmount conflictive and competitive forms of relations and establish relations of cooperation and mutual aid. Baas (1997) says that social capital is connected with social cohesion and identification with forms of government, and with cultural expressions and forms of social behaviour which make society more cohesive and represent more than a mere collection of individuals. He considers that horizontal institutional arrangements have a positive effect in generating networks of confidence, good government and social equity and that social capital makes an important contribution in stimulating solidarity and overcoming market failures through collective action and communal use of resources. Joseph (1998) sees such capital as a vast set of ideas, ideals, institutions and social arrangements through which people can find their voice and mobilize their individual energy for public causes. Bullen and Onyx (1998), for their part, see it as social networks based on principles of confidence, reciprocity and norms on the way to act.

Taking a more critical view, Levi (1996) acknowledges the importance of Putnam's findings but believes that it is necessary to place more emphasis on the ways in which the State can foster the creation of social capital. He considers that Putnam's interest in civil associations far removed from the State derives from his romantic view of the community and social capital. Such romanticism, he feels, restricts the identification of alternative mechanisms for the creation and use of social capital and limits theoretical conceptualizations of these matters. Wall, Ferrazzi and Schryer (1998) believe that the theory of social capital needs more refinement before it can be considered as a measurable generalization. Serageldin (1998) notes that although it is generally agreed that social capital is important for develop- ment, there is no general agreement among researchers and practical scientists on the particular ways in which it contributes to development, ways of generating and using it, and ways of materializing it and studying it empirically.

While the epistemological and methodological debate continues -a debate which is perfectly legitimate in view of the enormous complexity of social capital and the fact that it only began to be studied systematically less than a decade ago- such capital continues to provide proofs of its presence and effective action, and this is the aspect on which we intend to concentrate.

A broad line of research aimed at "recording it in action" is constantly providing new evidence of the importance of social capital in development. Thus, Knack and Keefer (1997) econometrically measured the correlation between confidence and norms of civic cooperation, on the one hand, and economic growth, on the other, in a broad group of countries, finding that the former have a strong impact on the latter. Their study also indicates that the social capital made up of these two components is greater in societies which are less polarized in terms of inequality and ethnic differences.

Narayan and Pritchett (1997) have made a very stimulating study on the degree of associativeness and economic performance in rural households in Tanzania. They discovered that even in this context of great poverty the families with the highest income levels were those that participated most actively in collective organizations and that the social capital they accumulated in this way benefitted them individually and also provided collective benefits in various ways. These families: i) used better agricultural methods than those of families which did not participate, as their participation provided them with information that led them to use more agricultural chemicals, fertilizers and improved seeds; ii) had better information on the market; iii) were willing to take more risks, because the fact that they formed part of a social network made them feel that they enjoyed a measure of protection; iv) tried to secure improvements in public services and participated more actively in school affairs, and v) cooperated more actively at the municipal level. These researchers state in their conclusions that the channels they identified whereby social capital increased income, and the econometric robustness of the magnitude of the effects obtained, suggest that social capital really is capital, and not just a consumer good. 
La Porta, López de Silanes, Shleifer and Vishny (1997) tried to confirm Putnam's theories in a broad sample of countries. Their statistical analyses show significant correlation between the degree of confidence existing in a society and such factors as efficiency of the legal system, absence of corruption, quality of the civil service and fulfillment of tax obligations. They consider that the results Putnam obtained for Italy are confirmed at the international level.

Teachman, Paasch and Carver (1997) tried to measure how social capital affects the educational performance of children. Using three indicators -family dynamics, links with the community and the number of times a child has changed schools- they found a strong correlation with a key performance indicator: the probability of dropping out of school. Their hypothesis is that social capital makes other forms of capital (such as human and financial capital) more productive.

The positive influence of a key component of social capital, the family, in numerous aspects has been confirmed by various recent studies. The greater the solidity of this basic social capital, the better the results, and vice versa. A broad study of 60,000 children in the United States (Wilson, 1994) showed that children living with only one of their biological parents were twice as likely to be expelled or suspended from school, to suffer from emotional or conductual problems, and to have difficulties with their schoolmates. They were also much more likely to engage in antisocial forms of conduct. Kaztman (1997) reports that, according to studies made in Uruguay, infant mortality among children born out of wedlock is much higher and children not living with both their biological parents suffer greater damage in various dimensions of their psychomotor development. Likewise, a study carried out in Sweden -in a totally different environment with much better economic conditions- shows that stable families have a positive influence on children's performance. Jonsson and Gahler (1997) show that children from divorced families have a lower educational performance. There is a loss of resources compared with those of children from stable families.

Sanders and Nee (1996) have analysed the family as social capital in the case of immigrants to the United States. Their studies indicate that the family environment creates conditions which make possible a key survival strategy for immigrants: self-employment. The family minimizes the produc- tion, transaction and information costs associated with such work, thus facilitating the appearance of family-run businesses. Hagan, MacMillan and Wheaton (1996) note that in migrations, even inside a country, there are losses of social capital, but these are smaller in families where the parents are involved with the raising of the children and the mothers carry out a protective role, but greater when the fathers and mothers do not devote themselves fully to their children.

Kawachi, Kennedy and Lochner (1997) provide some eloquent data on the relation between social capital, equity and public health. Their well-known study on Alameda County, subsequently confirmed by epidemiological studies in other communities, found that persons with fewer social contacts have a lower life expectancy than those with broader contacts. Consequently, a socially cohesive society which facilitates interpersonal contacts is a fundamental factor in public health. The authors statistically measured the correlations between social capital, as represented by confidence, and mortality in 39 states of the United States, and they observed that the lower the degree of mutual confidence among citizens, the higher was the average mortality. The same correlation was found between the rate of participation in voluntary associations and mortality: the lower the former, the higher the latter. They also introduced the degree of economic inequality into the analysis and found that the higher this degree, the lower the level of confidence that citizens had in each other. On the basis of the statistical model these researchers used, they found that for every percentage point that inequality of income distribution increased, mortality rose by two or three points over the level it ought to have registered. In order to illustrate their analysis, they used various comparative figures. Thus, in 1993, although the United States had one of the highest levels of per capita income in the world (US\$ 24,680), life expectancy (76.1 years) was lower than in some nations with lower per capita incomes, such as the Netherlands (US\$ 17,340 and 77.5 years), Israel (US\$ 15,130 and 76.6 years) and Spain (US\$ 13,660 and 77.7 years). It may therefore be asserted that more equal income distribution creates greater social harmony and cohesion and improves public health. Indeed, the societies with the longest life expectancy in the world (Sweden, 78.3 years, and Japan, 79.6 years) are also marked by very high levels of equity. These researchers therefore 
conclude that inequality reduces social capital and this seriously affects the health of the population.

Quite apart from the various speculations and efforts to secure greater methodological precision, valid and necessary though they may be, social capital does in fact operate every day and carries great weight in the development process. Hirschman (1984), a pioneer in these matters, has asserted something in this respect which is worthy of all our attention. He notes that social capital is the only form of capital which is not reduced or depleted with use but, on the contrary, increases: love or responsible civic behaviour are not fixed or limited resources, as other factors of production may be, but are resources that grow with use rather than diminishing.

Nevertheless, social capital can also be reduced or destroyed. Moser (1998) warns of the vulnerability of populations which are poor in social capital when faced with economic crises, noting that while households with adequate resources keep up their mutual relations, those which are poor in this respect withdraw from such relations at times of crisis because they are unable to fulfill their obligations. Fuentes (1998) shows how in Chiapas (Mexico) peasant groups which were forced to migrate suffered heavy losses of social capital, since their basic links and forms of social insertion were destroyed. Moreover, as a number of studies have pointed out, there may also be negative forms of social capital, such as criminal organizations, but their existence does not negate the immense potential of positive social capital.

Culture extends across all the dimensions of the social capital of a society, underlying the basic components of social capital such as mutual confidence, responsible civic behaviour, and degree of associativeness. The relations between culture and development are manifold, and it is amazing that so little attention has been given to them. Their importance becomes clear when we assign their due value to all these silent and invisible -but clearly activeelements involved in the idea of social capital.

Among other aspects, the values held by a society will strongly affect development efforts. As Sen (1997a) points out, the ethical codes of businessmen and professionals form part of the productive resources of society. If these codes place emphasis on values in keeping with the project of development with equity for which broad sectors of the population clamour, they will favour such development; if not, they will hinder it.

The values prevailing in the educational system, the communications media and other areas which influence the formation of values can either stimulate or obstruct the formation of social capital, which, as we have seen, considerably affects development. Chang (1997) notes that values raise the bases for the concern of one citizen for another above considerations of mere personal well-being and play a crucial role in determining whether there will be progress in terms of social networks, norms and mutual confidence. Values deeply rooted in the prevailing culture and either strengthened or impeded by it, such as solidarity, altruism, respect and tolerance, are essential for sustained development.

Culture is a key element in the fight against poverty. As UNESCO (1996) emphasizes, for the poor, their own values are often all they have to assert. Under-privileged groups have values which give them an identity of their own. Failure to respect these groups, and actions that lead to their marginalization, can be deeply harmful to their identity and may block even the best productive proposals. Their strengthening and reassertion, however, can set free enormous amounts of creative energy.

Culture is also a decisive factor in social cohesion, for through it persons can recognize each other's qualities, grow together and develop collective self-esteem. As Stiglitz (1998) notes in this respect, preserving cultural values is very important for development, as such values serve as a cohesive force at times when many others are flagging.

Social capital and culture can be formidable levers of development if the right conditions are created. In contrast, ignoring or destroying them makes the path to development much more difficult. It might be asked in this connection whether the idea of strengthening them is not something that belongs to a world of utopias: a future that is still far beyond the current possibilities of our societies. In the following section we will try to show that this is not so: that there are concrete examples where such levers have been used on a considerable scale to further development, and that there are lessons to be learned from them. 


\section{III}

\section{Social capital in action. Some Latin American examples}

What happens when a sustained long-term effort is made to mobilize key aspects of the social capital of a community? What responses have been observed? What new opportunities or difficulties arise? There is a very wide range of examples under way at the international level which can provide some significant indications in this respect. Some of them have become world-famous, such as the case of the Grameen Bank in Bangladesh, which provides financial support for poor peasants and has achieved surprising results by making use of elements connected with the degree of associativeness, mutual confidence, and other dimensions of social capital. Here, however, we will concentrate on examples from Latin America which show the region's latent potential in these matters. We have selected three cases which have obtained striking results, are recognized both in their own countries and internationally as "highly successful social practices", and are constantly analysed and visited in order to see if it is possible to imitate them wholly or partially.

\section{Villa El Salvador (Peru): from a sandy waste to an outstanding social experience}

In 1971, several hundred poor people invaded some publicly-owned land on the outskirts of Lima. They were joined by thousands of slum-dwellers from that city. The government stepped in to expel them, but finally agreed to let them settle on a extensive sandy wasteland 19 kilometres from Lima. Those 50,000 poor people, who lacked every kind of resources, set up the Villa El Salvador there. Over the course of time they were joined by many more people, and the present population of the Villa is estimated at nearly 300,000 . This case is considered to be very special in many respects. For example, the layout of Villa El Salvador is quite different from other poor settlements. The design provides for 1,300 blocks forming 110 residential groups. Instead of there being a single centre where the basic public buildings are located, the scheme is totally decentralized. Each residential group has its own centre, with communal premises and spaces for sports, cultural activities and social encounters. This favoured interaction and greatly increased the possibilities of cooperation, so that it was an organizational model based on active participation. Starting with representatives of the blocks and residential groups, the dwellers in Villa El Salvador created an organization -CUAVESwhich represents the whole community and has played a decisive role in its development. Almost 4,000 organizational units were set up to seek solutions and run community affairs, in which the great majority of the inhabitants are involved: almost 50\% of all those over 18 years of age occupy some kind of post in them.

In this wasteland, which lacked almost every kind of resources and was very isolated (the nearest means of access to Lima was 3 kilometres away), the inhabitants carried out a tremendous construction effort, based mainly on voluntary work by the dwellers in the Villa themselves. A survey of the situation at the end of 1989 shows that in less than two decades the inhabitants had erected 50,000 dwellings, 38,000 of them built with their own hands $(68 \%$ of them with solid materials such as bricks, cement, concrete roofs, etc.), they had constructed $2,800,000 \mathrm{~m}^{2}$ of roadways of beaten earth through their own efforts, and they had built 60 community premises, 64 educational centres and 32 community libraries, mostly with community labour and resources. In addition, there were 41 centres for integrated health, education and nutrition services, community health centres, a network of pharmacies, and a reasonably good internal road infrastructure with four main avenues and seven roads running across them. The inhabitants had also planted half a million trees.

The social achievements of Villa El Salvador were also very significant, even though its dwellers continued to be poor during this period and to suffer from serious problems of unemployment, like the rest of Lima. By 1989 the illiteracy rate had gone down from $5.8 \%$ to $3.5 \%$, while the rates of primary 
and secondary school enrolment had risen to $98 \%$ and $90 \%$, respectively: all figures that were better than the national averages and much better than in similar poor communities. In the field of health, the vaccination campaigns, which were carried out with community support and eventually covered the entire community, together with the organization of the community for preventive health care and family planning, had led to a sharp fall in infant mortality to 67 per thousand, compared with a national average of 88-95 per thousand. General mortality was also below the national average. Furthermore, there was significant progress in the installation of drinking water, drainage and electricity services, achieved in a period estimated to be 8 years less than that of other poor neighbourhoods, and there was considerable development of the community infrastructure, equipment and services, likewise faster than in other similar communities.

The enormous collective effort made has been described by the several times Mayor of Villa El Salvador, Michel Azcueta (Zapata, 1996) in the following terms: "The people of Villa El Salvador, through their efforts and struggles, have gradually built up a city from nothing, with hundreds of kilometres of water and electricity systems, roadways, schools, markets, an agricultural area, and even an industrial park, likewise achieved through the efforts of the small industrialists of the area".

This raises a basic question: How was it possible to achieve these results, starting from the most miserable poverty, in such an unfavourable natural setting, and in the midst of the acute economic crisis that Peru, like the rest of the region, was experiencing in the 1980s, to say nothing of all kinds of other difficulties? The key to understanding these achievements -which, while they did not eradicate poverty, nevertheless improved fundamental aspects of the lives of the Villa's inhabitants and turned it into a very different poor community- would appear to lie in elements coming under the concept of social capital.

The original settlers in Villa El Salvador were mostly families coming from the Sierra region of Peru. These Andean peasants had no material riches, but they did possess a wealth of social capital. They brought with them their ancestral culture and native traditions, together with thousands of years of experience of cooperation, communal work and solidarity. In the Villa they applied basic aspects of this culture, such as intensive community life and the coexistence of communal ownership of services that were vital to all with individual and family ownership of other things. This culture made it easier to set up this extensive participatory form of organization in which all the inhabitants were called upon to be actors in solving collective problems and which functioned smoothly thanks to the favourable historical background of Peruvian peasant culture. Intensive use was even made of age-old technical procedures, such as the leaching ponds used by the Incas: wastes were processed through a system of ponds which produced fertilizers that were subsequently used to improve green spots and agricultural production.

The importance of collective work as a way of achieving solutions, which was inherent in the culture of the inhabitants, permeated the history of the Villa right from the start. It is vividly reflected in the story of how the problem of building schools was tackled. Michel Azcueta recounts: “..... right from the start, the inhabitants organized themselves to build schools, so that the children would not lose the school year. Twelve school construction committees were formed in the first three months and work was started on the construction of a large number of classrooms, in an effort which now seems herculean and cannot be understood without an awareness of the subjective motivations behind it. Classes began to be given in classrooms with walls of reed matting, covered with plastic sheeting to keep out the winter cold, if only slightly, while the floor was beaten earth and the few bricks available were used as improvised benches for the children to sit on. These classrooms were built in collective efforts on Sundays, with a feverish enthusiasm which has left indelible memories among those who took part" (Zapata, 1996).

Thanks to these conditions, a broad and solid fabric of associativeness was created in the Villa. Organizations for young people, women and mothers were set up, as were market cooperatives, associations of small industrialists and shopkeepers, urban vigilance teams, juvenile coordination bodies and brigades, sports leagues, and cultural groups of all types. In the Villa, associativeness extended to the most varied aspects: producers who got together to buy inputs as a group, to look for machinery together and to improve the quality of their goods; over a hundred clubs for mothers, which organized and subsequently ran with exemplary efficiency 264 soup kitchens and 150 school milk programmes; young people who ran and promoted hundreds of cultural and artistic groups, community libraries, sports 
clubs, students' associations and social communication workshops.

The efforts of the community itself, organized on an eminently participatory basis, were responsible for all the progress that was made in such a short time. This process "sparked off" the latent social capital, which then proceeded to multiply. The creation of a whole municipality by its inhabitants, starting from nothing, generated a solid identity and heightened personal and collective self-esteem. As Franco (1992) notes, the city that was created in this way was the expression of its inhabitants. They were not merely its dwellers, but also its creators. In creating and developing Villa El Salvador they were creating themselves. Consequently, when one asks the inhabitants of the Villa where they come from, they do not answer like other settlers who have come from the interior, who name their birthplace, but say instead "I am from the Villa": the place that gave them the identity they prize so highly. The process of facing very difficult challenges and overcoming them was also a process of strengthening their self-esteem, which is the fundamental incentive for productive action. As Franco says, when one attends a fair number of community meetings and talks to the founders or leaders of the community one frequently hears expressions of collective self-confidence, assertions that the inhabitants now possess organized power, and a noteworthy faith in the community's capacity to set itself goals and unite to achieve them.

Self-esteem was also specially cultivated in the schools of the Villa, where the teachers tried to free the children from any feeling of inferiority because they came from poor families and sought to give them a sense of security so that they would not feel at a disadvantage.

The community effort to build the Villa El Salvador, which took place in the most difficult conditions, was marked and guided by certain values. The inhabitants defined their project as the formation of a community with participatory self-government. The whole effort was imbued with a collective vision centered on the promotion of community values, active participation and self-government. In 1986 Villa El Salvador officially became a municipality, but in this process it preserved all the foregoing principles. Thus, it was laid down that all municipal decisions should be based on communal decisions. Recently, with the aid of various non-governmental organizations, the newspaper "El Comercio" and other bodies, the Villa introduced a system designed to facilitate the inhabitants' participation through informatics. Under this system, the Municipal Council transmits its sessions to the Villa by closed-circuit television. Within the Villa there are computer terminals through which the inhabitants can receive information on the matters to be dealt with at the sessions and the relevant background, and they can make their views known to the Council, which also holds ongoing referendums to find out the inhabitants' views, using the same computerized system.

The experience of the Villa has won world recognition and received many awards. In 1973 UNESCO distinguished it with an award as one of the most challenging experiences in popular education; in 1987 the United Nations named it "Messenger of Peace" as an exemplary promoter of forms of community living, and in the same year it also received the "Príncipe de Astúrias" prize from the King of Spain. Pope John Paul II paid a special visit to it in 1985 and delivered an address in the Villa in which he highlighted its achievements.

It has not been possible in the Villa to solve the underlying problems causing poverty, since these have to do with factors that go completely beyond the ambit of this venture and form part of the general problems of the country at large. Nevertheless, considerable advances have been made compared with other poor settlements, and a very special profile of society has been developed. The strengthening of social capital has played a decisive role in the Villa's achievements. Invisible, silent factors that operate at the very heart of the social fabric have had a constant positive effect here. They include ongoing development of all forms of cooperation; mutual confidence among the organizing actors; the existence of a community-oriented, constructive and creative form of civic behaviour; the presence of common guiding values; the mobilization of the community's own culture; the assertion of personal, family and collective identity, and the greater self-esteem stemming from the experience itself. All these elements were boosted by the genuinely participatory model adopted by the community.

\section{The Family Consumption Markets of Venezuela: the dividends paid by social capital}

The question of how to reduce the cost of foodstuffs for the poorer sectors of the population has found a significant response in the city of Barquisimeto, 
TABLE 1

Venezuela: Expansion of the Barquisimeto Family Consumption Markets

\begin{tabular}{|c|c|c|c|}
\hline & 1984 & 1990 & 1997 \\
\hline Sales units & 1 & $87^{\mathrm{a}}$ & $105^{\mathrm{b}}$ \\
\hline Weekly sales of fruit and vegetables (tons) & 3 & 168 & 300 \\
\hline Number of families served & 300 & 20000 & 40000 \\
\hline Number of workers & 15 & 400 & 700 \\
\hline Number of agricultural producers & 15 & 100 & 500 \\
\hline Number of producers' organizations & 1 & $\mathrm{n} / \mathrm{d}$ & 18 \\
\hline Number of community production units & 1 & 9 & 12 \\
\hline
\end{tabular}

Source: Gómez Cálcano (1998) and data from CECOSESELA (1990-1997).

${ }^{a}$ Includes the whole of the state of Lara; Barquisimeto accounts for approximately half of this amount.

${ }^{\mathrm{b}}$ Includes 50 markets and 55 social supply centres.

Venezuela, where the Family Consumption Markets, which began in 1983, have succeeded in reducing the retail prices of fruit and vegetables by $40 \%$ and those of other foodstuffs by between 15 and $20 \%$, benefitting 40,000 families per week in this city of a million inhabitants. These families, which are mostly from the lower and lower middle strata, are estimated to save a total of US\$ 10.5 million by buying food in these markets.

The markets involve a considerable number of civil organizations. Formally, they come under the Central Council of Cooperatives of the state of Lara (CECOSESELA), but various groups of producers, consumers' associations and small self-run enterprises take part in running them. Thus, they include 18 associations of agricultural producers, grouping together nearly 600 farmers, and 12 community production units. All these small and medium-sized farmers and food producers sell their output through the Markets, which have 50 sales points, operating in the last three days of the week, and sell 300 tons of fruit, vegetables and staple foodstuffs directly to the population every week for household consumption.

Basically, the Markets sell fruit and vegetables by kilos at a flat rate, which simplifies their operation to the maximum. Among the products they sell are potatoes, tomatoes, carrots, onions, sweet peppers, lettuce, celery, cabbages, bananas, and various local tropical products. Through their own transport facilities and sales premises they bring goods directly from small producers to the consumers, so that everyone wins: the small producers, who were among the original creators of this initiative, since they previously suffered all the problems and fluctuations of marketing, now have an assured outlet for their goods at reasonable prices, while consumers receive fresh products at much less than normal market prices.

The Family Consumption Markets have grown rapidly into the main supplier of foodstuffs and staples for the city of Barquisimeto (table 1).

As may be seen from the table, starting from a single sales point and almost no initial capital, the Markets have grown rapidly in all the indicators listed. Between 1990 and 1997 the weekly tonnage of fruit and vegetables sold increased by $78 \%$, while the number of families served doubled.

How could such economic success and efficiency be obtained by a set of grass-roots organizations which had little or no capital yet launched out into an agricultural and food products market characterized by its strong competition and low profit margins?

It would appear that key elements of social capital lay at the roots of this success. The actors in this venture themselves say that their achievements were based on: i) a history of social and human capital formation; ii) giving priority to social rather than financial capital, and iii) some novel forms of participatory management (Ferias de Consumo Familiar, 1996).

The several hundred workers who keep the Markets and the associations linked with them going have established a system of organization which is based on cooperation, participation and horizontality and is strongly guided by a set of values.

Underlying the Markets is a conception of life which, according to the actors involved, gives priority to solidarity, personal and group responsibility, transparency in relations, the creation of mutual confidence, personal initiative, and a readiness for hard work. 
This set of values is not just something that exists in a written declaration, as often happens, but is fostered systematically. An outside observer (Bruni Celli, 1996) describes the everyday dynamics of the Markets as follows: "The cooperativist values of personal growth, mutual support, solidarity, frugality and austerity, as well as of teaching others, avoiding selfish attitudes and always doing one's best on behalf of the community, are matters of continual reflection at the eight or more hours of meetings that all the workers in CECOSESELA attend every week. The large number of hours spent on meetings might be seen as a loss of productivity, but in fact they are the main means for achieving the dedication, enthusiasm and commitment of the workers in the organization".

Within the context of these values, the organizational design adopted seems to have played a decisive role in the results obtained. It is centered on such principles as the active participation of all members of the organization, fluid communication at all levels, joint analysis and learning, and continuous rotation of tasks. One of its features is that all the hundreds of workers in the organization earn exactly the same wages $(57 \%$ higher than the national minimum wage). The organization has also set up a credit union which lends money at low rates and an integrated health fund. Although the wages are only modest, the members of the organization have stated that they have other incentives, such as forming part of a project with such admirable values, working in a democratic and non-authoritarian environment, and having possibilities for training and development.

The concrete organizational mechanisms of the organization include: weekly meetings of each group for assessment and planning purposes; decisionmaking by consensus; shared information; collective discipline and supervision; decentralized work by each group, and the rotation of tasks already mentioned earlier. In addition, there are meetings known as "get-togethers" designed to foster closer personal and social relations.

These features of the system of organization coincide with many of the recommendations of modern management science. They are conducive to what is called nowadays a "learning organization" or an "intelligent organization". The organizational model of the Markets is very flexible, and this allows them to absorb through all their "pores" information on what is happening around them, which, when shared inter- nally, increases their capacity to react to any changes that take place. It also allows them to follow up processes as they take place, rapidly detecting any errors. The climate of confidence created among their members avoids the heavy costs of mistrust and constant confrontation which are typical of some other organizations. On the contrary, the elements of the model foster a profound sense of belonging which is a fundamental stimulus of productivity.

The Markets have successfully survived all the forecasts that they would find it very difficult to resist the problems of the market: indeed, they are now in a leading position in their market and are obliging other business competitors to try to adjust their own prices. They have become the main supplier of staple foods for Venezuela's fourth biggest city and, although they only operate locally, their operating figures show them to be one of the biggest food marketing companies in the whole country. They have shown themselves to be completely sustainable and over 15 years they have been steadily expanding their operations.

They are now giving rise to imitators in various other Venezuelan cities. The key to their excellent performance does not lie, in this case, in heavy capital investments managed according to conventional business criteria of maximizing profits or in a vertical form of management. Instead, the capital they have mobilized is essentially "social capital". They have promoted certain values that are latent in civil society; they have demonstrated the possibility of carrying out a collective project which is at once efficient in productive terms, socially useful and attractive as a context for living, and through their special style of management, which they have called "solidary management", they have heightened basic elements of the accepted concept of social capital, such as associativeness, mutual confidence and norms of behaviour which favour community life and objectives.

Local analysts such as Machado and Freites (1994) note that they have also taken advantage of the great store of social capital existing in the state of Lara, which is the Venezuelan state with the largest number of cooperative organizations. In 1994 there were 85 cooperatives in the state, 36 of them providing multiple services, as well as a dense network of non-governmental organizations (over 3,500) and numerous neighbourhood associations and other forms of social organization. We can thus see that in the 
state of Lara there is a whole cultural habitat that favours the development of social capital and has provided fertile ground for a project of this nature.

\section{The participatory municipal budget of Porto Alegre (Brazil): expanding the existing social capital}

The experiment in participatory municipal budgeting which was begun in the city of Porto Alegre in 1989 has become one of the "star" experiments at the international level and has attracted widespread attention. Nearly 70 Brazilian municipalities are now undertaking similar experiments inspired by that of Porto Alegre.

This interest on the part of other cities and countries is due to the concrete results obtained. In 1989 Porto Alegre, which has 1.3 million inhabitants, suffered from serious social problems and broad sectors of its population had only limited access to basic services. There was also an acute shortage of fiscal resources. The newly-elected Mayor decided to invite the population to cooperate in managing the investments section of the municipal budget. This time, the invitation was not mere hot air but was backed up by a complex and elaborate system to make mass participation possible. The city has been divided into 16 zones, for each of which the budgetary execution figures and future estimates are analysed and priorities are identified at the neighbourhood level, with the results being subsequently assembled and harmonized at the zonal and global levels. In addition to the zones, there is another analysis and decision-making mechanism which operates in respect of major matters of urban concern: urban development, transport, health services, leisure facilities, education and culture. The public at large, elected representatives and municipal officials take part in working groups, intermediate-level meetings, plenaries and other types of meetings held throughout the year. The budget is thus formulated from the bottom up and is finally formally adopted by the Municipal Council.

The population responded to the Mayor's invitation with what Navarro (1998) called "feverish participation". It is estimated that in 1995100,000 people took part in the process.

The results have been surprising and have dispelled the pessimistic forecasts that the "inadmissible heterodoxy" of submitting such a highly technical and delicate matter as the budget to a popular partici- pation process would be a failure. On the one hand, the population determined its real needs and redirected resources towards the most keenly felt problems. On the other, the whole budgetary process, which had previously been closed and impenetrable, was completely opened up for citizens at large. The fact of sharing the whole of the information with them made the whole process transparent, thus creating favourable conditions for the eradication of all forms of corruption. The public engaged in a mass exercise of social control of the preparation and execution of the investment section of the budget, which represented $15 \%$ of the total budget and in 1989/1995 amounted to US\$ 700 million. Furthermore, by establishing clear rules on the nature of the decision-making process, this initiative reduced to the minimum the room for arbitrary clientage-type practices.

The fact that the budget now corresponds to priority needs, together with the improvement in its management, led to very significant results. Thus, between 1990 and 1996 the number of homes with drinking water supply rose from 400,000 to 484,000 , so that it covered $98 \%$ of the population, while in the case of sewerage, whereas in 1989 only $48 \%$ of homes were connected to the sewerage system, by 1997 the proportion had risen to $80.4 \%$ (the average for the whole of Brazil was only 49\%). Likewise, 167,408 persons (13\% of the population) were benefitted between 1990 and 1996 by the programme for issuing official titles for land ownership in poor sectors and settlements. In the poorer areas of the city, 30 kilometres of streets were paved each year, while in the field of education primary and secondary school enrolment rose by $159 \%$ between 1989 and 1997 and the municipality established an adult literacy training programme which had 5,277 participants in 1997.

Since this system was introduced, the identification of priorities in line with real needs, together with the effects of the system as a whole, have brought about a large-scale reallocation of resources which, aided by the collective participation of the community in following up the budget execution process, has made possible the impressive achievements obtained. The population have now become a major actor in the municipal budgetary process.

The broad support among the population for profound budgetary changes has also been expressed in strong pressure for measures to make the tax 
system of the municipality more progressive and efficient, and major reforms have been made which have allowed tax revenue to be increased while making its collection more equitable.

All in all, there have been appreciable changes in the traditional political image of the municipality, which was previously like many others in the region: there has been a redistribution of functions between the municipality and civil society; the latter has become much more active; various forms of direct democracy have been introduced; the room for corruption has been very sharply reduced, by making the management of the public finances so transparent and closely monitored; conditions are now unfavourable for clientage-type practices, and decision-making has been decentralized.

This process has been based on the utilization of the social capital which already existed in this society, where there was a substantial tradition of community associations. These associations were actively mobilized and played a fundamental role at the various levels of decision-making that were established. As Navarro points out, a decisive factor was the political will of the Mayor to get away from the usual systems of concentration of power and instead invite the population and the associations in question to share the power with him. This invitation and the establishment of genuine participation mechanisms served to amplify the existing social capital. The capacity for cooperation increased enormously, a climate of mutual confidence was established among the actors, and strong incentives were created for constructive civic behaviour. The already existing associative culture was an essential element in promoting popular participation, while it in turn was greatly strengthened by the process, which has shown the potential that is revealed when the false conflicts between the State and civil society are overcome and they join together to work for the common good.

In Porto Alegre, social capital behaved as Hirschman (1984) forecast that it would: when more intensive use was made of it, it expanded. This was recognized by the IDB (1997), when it noted that the participation process has had an enormous impact on the ability of citizens to respond to challenges in an organized manner, as a community, and on their capacity to work together to improve the quality of the public administration and, hence, their quality of life.

\section{Some lessons to be drawn from the above cases}

The cases described above have had important effects, have shown strong sustainability, and have won recognition in many circles. What were the keys to their success? Although they were carried out in very different environments, can some common elements be identified in them which have significantly affected their results?

Firstly, the strategies employed have been based on the use of non-traditional forms of capital, by promoting the entry into action of forces which were latent in the social groups. In all the cases analysed, the capacity to seek solutions and implement them in a cooperative manner was brought into play; a climate of mutual confidence was built up among the actors; the existing cultures of the actors were taken as the starting point, totally respected and fostered, and a style of civic conduct based on solidarity and concern for the general good was promoted. The encouragement of these and other similar factors gave rise to community and organizational forces which were capable of carrying out extensive constructive efforts in spite of the misery originally reigning in the Villa El Salvador, the extremely small resources available for the Consumer Markets in Barquisimeto, and the limited resources and deficits in Porto Alegre.

A second common feature was the adoption of a totally non-traditional organizational design. In all three cases the basis of this design was the organized participation of the community. In a recent study (Kliksberg, 1998) we made a detailed analysis of the organizational possibilities offered by participation. In that study we noted, on the basis of the comparative analysis of different international experiences and a broad range of empirical information, that participation has considerable competitive advantages over the usual hierarchy-based designs, and we identified the mechanisms through which such advantages are generated. Indeed, participation is now an essential part of the management models of the most advanced organizations in the world.

A third distinctive feature of the three cases studied is that, underlying the mobilization of social capital and culture and the designs for open and democratic management, there was a value-based conception which was of decisive importance. Without it, it would have been impossible to solve the many difficulties encountered on the innovative and non-traditional path that was followed. The values 
maintained served as a continuous source of guidance and at the same time powerfully motivated the behaviour of the communities concerned and transmitted the inspiring vision of the final goals to those at whom the efforts were directed.

Other projects are being carried out in the region which, while having their own special features, follow lines like those described above to a greater or lesser extent, as well as adding new elements of their own. Their results are highly significant. Among many others, mention may be made of the EDUCO programme in El Salvador, based on the self-organization of poor peasant families to run rural schools; the school milk programmes in Peru; the role played by organized indigenous communities in Bolivia and Ecuador, and parent participation in running the schools in Minas Gerais.

It could be argued -and indeed this has been done- that projects of this type have only a limited scope. However, experience shows that although considerable difficulties have been encountered and that these projects cannot easily be extended to other environments, they can nevertheless make formidable contributions: they directly improve the quality of life of broad under-privileged sectors, they are a testbed for advanced forms of social action, and they represent an inspiring appeal to progress in this direction.

In the final analysis, mobilizing social capital and culture as active agents of economic and social development is by no means a utopian proposal: it is perfectly viable and gives effective results. There is significant past experience on which to base action. In order to carry out this mobilization on a major scale -a great challenge for the future- comprehensive policies and broad consensus between the State and civil society will be needed.

\section{IV}

\section{It is time to mobilize the potential of culture}

From the standpoint of economics, cultural activities have often been regarded as a secondary field foreign to the central line that economic growth should follow. They have often been treated in practice as a field which absorbs much-needed resources, does not generate economic returns on the investment made in it, gives effects which are difficult to measure, and tends to be poorly managed. On the other hand, there has also been a certain tendency in the field of culture itself to adopt a closed attitude and not actively seek links with economic and social programmes, which has led to a serious gulf between culture and development. This situation causes great losses for society: it seriously hinders the advance of culture, which comes to be treated as a secondary aspect which involves only expense and delivers little benefit, while at the same time it has a high opportunity cost, as it does not take advantage of all the contributions that culture could make to development processes.

In order to bridge this gulf, systematic efforts are needed. Culture is an important part of social capital, as shown both by the cases described earlier and by the many others currently under way. The crisis of conventional economic thinking has opened up an opportunity -as part of the search for a broader and more integral view of development- for the incorporation in their own right of the cultural dimensions of the latter.

Before exploring some of the possible points of interaction, a very important point should be noted. Culture can be a formidable instrument of economic and social progress, but its identity does not end there. It is not just an instrument. The cultural development of societies is an end in itself, and progressing in this field means furthering the spiritual and historical enrichment of a society and the individuals that make it up. As the Report of the World Commission on Culture and Development (UNESCO, 1996) declares, it is an end which is desirable in itself, because it gives a meaning to our existence. This aspect should never be lost from view.

The distinguished economist Françoise Benhamou makes some telling remarks in this respect: "In reality, only under an out and out economistic approach could it be suggested that expenditure on culture should be justified in the light of the tangible benefits that it can generate in return. The gains that cultural life can bring to the community do not always cover the expenditure involved. 
Obviously, the justification for this expenditure should be assessed in the light of other criteria which go beyond the economic dimension". She calls for the use of different criteria to measure the "performance" of something which is, in the final analysis, one of the ultimate ends of society. She warns against the mechanical application of criteria usually employed in the economic field and the facile and erroneous conclusions that can be drawn from them, emphasizing that "It would be lamentable if, at a time when economic science acknowledges the value of the qualitative dimension of the object being appraised, economists were to insist on taking account only of the commercial results of investments in culture. Is there any reason to complain about the cost of cultural life, which is really very modest? Should we not rather see in it the image of an adult and prosperous nation?" (Benhamou, 1997).

In addition to being an end in itself, culture has enormous potential that can be mobilized for development, including that briefly described below.

\section{Culture and social policies}

The mobilization of culture can be a very valuable factor in the fight against poverty, which currently afflicts nearly half the inhabitants of the region. The intangible underlying elements of culture can help in many ways.

The poor do not have material wealth, but they do have a store of culture that often goes back for hundreds or even thousands of years, as in the case of the indigenous peoples. A deep respect for their culture will create favourable conditions for making use in social programmes of their accumulated knowledge, traditions, ways of linking up with nature and their natural cultural capacity for self-organization, all of which can be extremely useful.

Furthermore, consideration and due appreciation of the culture of under-privileged sectors is a key point in the crucial matter of collective identity and self-esteem. Economic marginality and poverty are often accompanied by the depreciation of cultural values. The culture of the poor is looked down upon by other sectors of society as being inferior, precarious, backward. Cultural patterns of the poor are sometimes even irresponsibly blamed for being responsible for their poverty. The poor feel that, apart from their material difficulties, they are facing a silent process of "cultural depreciation" of their values, traditions, knowledge and forms of relations. In the final analysis, depreciating their culture means weakening their identity, and a weakened identity gives rise to feelings of low individual and collective self-esteem.

A major aim of social policies should be to reverse this process and raise the collective and personal self-esteem of under-privileged groups. Stronger self-esteem can be a powerful constructive and creative force. The essential means for this is culture. The promotion of popular culture, the opening-up of channels for its expression, its cultivation among the younger generations, and the creation of a climate of genuine appreciation of its content will cause culture to grow and, together with this, will restore their identity to impoverished groups.

There are some interesting examples of actions of this type in Latin America. Among them are the energetic efforts made in Venezuela in recent decades to form popular choirs and musical groups. By dint of sustained efforts in various communities, many of them poor, groups have been set up which have brought together thousands of children and young people, mainly for the interpretation of music whose roots are in popular culture. These cultural spaces, as well as allowing their members to express themselves and grow artistically, also cause them to love and value their culture and strengthen their identity. They have also had some effects that were not originally foreseen. Thus, the systematic practice of these activities has also fostered habits of discipline, hard work and cooperation. Similar efforts have also been made on a large scale in recent times in Colombia and other countries.

\section{Culture and social integration}

One of the basic problems of Latin American societies is social exclusion, which severely hinders the access of some sectors to the labour and consumer markets and makes it impossible for them to integrate into society. These obstacles mutually heighten each other, thus forming regressive vicious circles.

The democratization of culture can break these circles in an important respect. The creation of cultural spaces open to the under-privileged sectors, with special stimulation for them to use them, can give rise to novel channels of integration.

Culture can also significantly strengthen the educational capital of poor communities. The region is 
marked by high rates of dropping out or repeating courses in primary education among such communities (almost half the children leave school before completing six school grades). Every possible effort should be made to improve this situation. At the same time, however, cultural activities could act as a para-educational system, offering informal training facilities to complement and back up the school system. This would be particularly valuable for the many adults who dropped out of school when they were young.

Culture can be an attractive and realistic framework for the integration of the great numbers of young Latin Americans who are currently neither in the labour market nor the educational system, thus forming a population group in great danger of slipping into crime. The studies on the great increase in the crime rate in the region in recent decades indicate that a growing percentage of criminals are young and display a profile of unemployment and limited education. In cultural spaces, this group can be offered alternatives that can permit them to gain a sense of belonging socially and achieve personal growth.

Culture can make an effective contribution to the most fundamental social integration institution: the family. Research carried out in recent years shows that, in addition to its decisive affective and spiritual role, the family has an outstanding influence in many other areas too. It exerts a strong influence on the educational performance of children, the formation of creativeness and capacity for constructive criticism, the development of emotional intelligence, and the acquisition of a culture based on preventive health. At the same time, it is one of the main social safety nets and the prime, fundamental framework for social integration.

In Latin America, the impact of poverty has put many families in the humbler strata of society under great stress, so that they are in a state of crisis. It is estimated that over $20 \%$ of the families in the region are headed only by the mother. In the great majority of cases, these families are very poor. Likewise, there has been an increase in the number of children born out of wedlock, which is an indicator of the reluctance of young couples to form stable families, often because their economic difficulties make it hard to maintain a family.

Cultural spaces can help to strengthen this vital institution, whose contributions to society are incalculable. Joint activity by family members in these spaces can forge stronger links among them. Likewise, families can find stimuli and responses in them, can enrich their personal situation, and can share experiences with other family groups faced with similar problems.

\section{Culture and values}

The values of a culture have a decisive weight in development. In recent years there has been extensive debate on the types of values which have helped countries to attain sustained growth and significant social achievements.

If the dominant values are concentrated on individualism, indifference to the fate of others, lack of collective responsibility, lack of interest in the general good, the pursuit of personal enrichment as the central value, consumerism, and similar goals, the consequent forms of conduct may be expected to cause serious harm to the fabric of society and to lead to all kinds of regressive effects, ranging from severe economic inequity -which, according to many studies, gives rise to serious hindrances to sustained economic development- to a decline in social cohesion which may even affect average life expectancy. ${ }^{1}$ One of the visible effects of the prevalence of values that do not prize solidarity is the spread of corruption in a number of societies. As Arizpe (1998) notes: "This tendency has been largely fostered by the monotonous insistence on the idea that getting rich is the only goal that is worth while in life".

In contrast, positive values lead in very different directions. Thus, for example, societies which have stimulated and cultivated values that favour equity and taken steps to ensure that they are reflected in their tax systems, universal coverage of health services, and good-quality education have now attained good levels in all those fields, which have facilitated their economic and technological progress and their competitiveness. Examples of such countries include the Scandinavian countries, Canada, Japan, Israel, etc.

\footnotetext{
${ }^{1}$ For a pioneering study on the incidence of values on everyday life and the social fabric in Chile, see UNDP(1998a). This study explores the inner world of people and the quality of their relationships with others, makes some highly important findings in terms of social capital, culture and development problems, and identifies the existence of widespread social malaise in Chilean society, due, among other things, to the weakening of personal interrelations.
} 
Culture is the basic area in which a society generates values and transmits them from generation to generation. In Latin America, the systematic promotion and dissemination of values such as solidarity (which is deeply rooted in the local indigenous cultures), cooperation, mutual responsibility, joint concern for the collective good, the elimination of various forms of discrimination, the eradication of corruption, democratization ${ }^{2}$ and the pursuit of greater equity (in a region which is so flagrantly unequal) would obviously help development, as well as helping to shape the profile of society.

Notable results have been achieved in this respect by societies which have consistently cultivated voluntary action among the new generations. Such voluntary action incorporates many of the above-mentioned values. It is of great educational value, produces significant economic results by adding many hours of unpaid work to programmes which are of value to society, and promotes attitudes of solidarity and cooperation. In a number of countries volunteers form a substantial percentage of the total work force in the social sector: their activities are valued by the whole of society and represent a means of attracting many young people. There are substantial contingents of volunteers, for example, in the Scandinavian countries, Canada, various Western European countries, and Israel. Faigon (1994) reports that $25 \%$ of the population of Israel carries out regular voluntary work, particularly in the social field, and generates goods and services equivalent to $8 \%$ of GDP; he notes that the bases for these results lie in Jewish culture itself, which emphasizes that voluntary service to the community is a duty, and in the systematic inculcation of solidarity-based values in Israeli schools.

The cultivation of values through culture and participation from an early age in voluntary activities and community work exerts a considerable influence on the subsequent acquisition of civic commitments by adults, conclude Youniss, McLellan and Yates (1997) in the light of recent research. There is a statistical correlation between the fact of having acted in voluntary organizations when young and subsequent involvement with society. Thus, a study carried

\footnotetext{
${ }^{2}$ See, in this respect, the studies prepared under the Regional Project on Culture and Democracy led by Saul Sosnowsky, Director of the Institute of Latin American Studies of the University of Maryland.
}

out in the United States shows that those who had been members of $4 \mathrm{H}$ clubs were twice as likely, 25 years later, to be members of civic organizations, compared with those who had not formed part of such clubs, while they were four times as likely to participate in politics. Another study on graduates of secondary schools showed that 15 years later those who had taken part in extracurricular activities at school were much more likely to be participating in voluntary organizations. Such values and participation mould what the authors call a "civic identity" that encourages entry into commitments with the community and ongoing contributions to it.

An interesting experiment aimed at promoting cultural values useful to society was begun recently in Norway. On 30 January 1998 that country established the Government Commission on Human Values, which has four main purposes: i) to create an increasing awareness of values and ethical issues in society; ii) to foster a better knowledge of the development of human values in present-day culture; iii) to identify current ethical challenges in society and outline possible responses to them, and iv) to encourage the different sectors of society to take part in this debate.

The members of the Commission come from various sectors of society and belong to different generations. The aim of their activities is to ensure that value issues are at the centre of the public agenda and are analysed by both public and private institutions, that ethical dilemmas are identified and explicitly stated, and that suitable responses are sought. Among the first initiatives put into effect by the Commission is the requirement that all the schools in the country should examine how far the rights proclaimed in the United Nations Declaration of Human Rights are being applied in their areas. It is also promoting studies at the municipal level -it is seeking to decentralize many of its actions- on the tensions suffered by children and young people because of the frequent contradiction between the values imparted in the home, at school and in church and those that are given by the mass media. Another project seeks to create greater awareness with regard to responsibility, solidarity and participation, while yet another calls upon the Mayors of the various municipalities of the country to set in motion a process of deliberation at the local level to determine what the basic features of a good local community should be. 
The cultural potential of Latin America -which is enormous, as its fertile production in so many fields of art shows- can take shape in the form of important contributions to the fight against poverty, the development of social integration, the strengthening of values in the fields of community action, solidarity and participation, and many other areas. Mobilizing this potential calls for concerted action between the State and the various organizations of civil society, which must coordinate their efforts and do their very best in order, together, to set free the enormous forces of popular cultural creativeness which are latent in the region.

There are serious shortcomings in Latin America in this respect. While some sectors make great efforts to promote culture and secure important concrete results in this way, there are other sectors which display reservations and hang back from the task of giving culture a central place on the development agenda. Thus, cultural efforts are deprived of resources, are made a preferential target for budgetary cuts, and are subjected to constant changes which deprive them of the stability needed to place activities and institutions on a firm basis. It is usually argued that culture is a kind of secondary need to be filled when other more "urgent" needs have been satisfied. In some cases, this leads to a situation like that described so well by Pierre Bourdieu: “.... the absence of culture is usually accompanied by the absence of any awareness of its absence". ${ }^{3}$

For these reasons, and because of these practices, society is failing to make use of one of the great forces for securing profound changes in the actual conditions of a continent which is facing such difficult challenges in fields like poverty and inequality that decisively affect the everyday life of the population. $^{4}$ The time has come to overcome these shortcomings and actively explore the many contributions that culture can make to development.

(Original: Spanish)

\section{Bibliography}

Arizpe, L. (1998): La cultura como contexto del desarrollo, in L. Emmerij and J. Núñez del Arco (eds.), El desarrollo económico y social en los umbrales del siglo XXI, IDB, Washington, D.C.

Baas, S. (1997): Participatory institutional development, paper presented at the Conference on Sustainable Agriculture and Sand Control in Gansu Desert Area, http://www.worldbank.org/poverty/acapital/index. htm.

Benhamou, F. (1997): Economía de la cultura, Montevideo, Ediciones Trilce.

Bruni Celli, J. (1996): Las ferias de consumo familiar de Barquisimeto, Caracas, mimeo.

Bullen, P. and J. Onyx (1998): Measuring social capital in five communities in New South Wales, Working paper series, No. 41, Sydney, Australia, University of Technology, Center for Australian Community Organizations and Management (CACOM).

Chang, H. N. (1997): Democracy, diversity and social capital, National Civic Review, vol. 86, No. 2, San Fernando, California.

Chile, Presidencia de la República (1998): "Declaración de Santiago", Second Summit of the Americas, Santiago, Chile.

Coleman, J. (1990): Foundations of Social Theory, Cambridge, Massachusetts, Harvard University Press.

Faigon, Y. (1994): El voluntarismo en la sociedad israelí, paper presented at Encuentro BID - Congreso Judío
Latinoamericano. La lucha contra la pobreza a fines del siglo $X X$, Washington, D.C., Inter-American Development Bank (IDB).

Ferias de consumo familiar de Barquisimeto (1996): La experiencia de las Ferias, Barquisimeto, Venezuela, mimeo.

Franco, C. (1992): Imágenes de Villa El Salvador, in B. Kliksberg (ed.), ¿Cómo enfrentar la pobreza?. Aportes para la acción, Buenos Aires, Grupo Editor Latinoamericano.

Fuentes, M. L. (1998): Chiapas: el capital social perdido, Mexico City, mimeo.

Gómez Cálcano, L. (1996): Las ferias de consumo familiar del Estado Lara, Venezuela. Una experiencia de organización participativa, paper presented at the Seminar on Social Programmes, Poverty and Citizen Participation, Cartagena, Colombia, IDB.

Hagan, J., R. MacMillan and B. Wheaton (1996): New kid in town: Social capital and the life course effects of family migration on children, American Sociological Review, vol. 61, No. 3, Washington, D.C., American Sociological Association.

\footnotetext{
${ }^{3}$ Quoted in Benhamou (1997).

${ }^{4}$ For some recent studies on new forms of poverty in Latin America, see Kliksberg (ed.) (1993). The question of inequality is dealt with in detail in Kliksberg (1999).
} 
H.H. John Paul II (1996): Palabras en su visita a Villa El Salvador, 5 de febrero de 1985, in A. Zapata, Sociedad y poder local. La comunidad de Villa El Salvador, 1971-1996, Lima, Centre for Development Research and Promotion.

Hirschman, A. O. (1984): Against parsimony: Three easy ways of complicating some categories of economic discourse, The American Economic Review, vol. 74, No. 2, Nashville, Tennessee, American Economic Association.

IDB (1997): Libro de consulta sobre participación, Washington, D.C.

Iglesias, E. (1997a): Cultura, educación y desarrollo, paper presented at the General Assembly of UNESCO, Paris, United Nations Educational, Scientific and Cultural Organization (UNESCO).

-(1997b): Foreword, L. Emmerij and J. Núñez del Arco (eds.), Economic and Social Development into the XXI Century, Washington, D.C., IDB.

Jonsson, J. O. and M. Gahler (1997): Family dissolution, family reconstitution and children's educational careers: Recent evidence of Sweden, Demography, vol. 34, No. 2, Madison, Wisconsin, University of Wisconsin, Center for Demography and Ecology.

Joseph, J. (1998): Address: Democracy's social capital: civil society in a new era, Pretoria, South Africa, 15 January, http://www.worldbank.org/poverty/acapital/ index.htm.

Kawachi, I., B. Kennedy and K. Lochner (1997): Long live community. Social capital as public health, The American Prospect, No. 35, Cambridge, Massachusetts, November-December.

Kaztman, R. (1997): Marginality and social integration in Uruguay, CEPAL Review, No. 62, LC/G.1969-P, Santiago, Chile, Economic Commission for Latin America and the Caribbean (ECLAC).

Kliksberg, B. (1998): Seis tesis no convencionales sobre participación, Revista instituciones y desarrollo, Barcelona. United Nations Development Programme (UNDP), Red de Gobernabilidad y Desarrollo Institucional.

- (1999): Desigualdad y desarrollo en América Latina. El debate postergado, Reforma y democracia, No. 14, Caracas, Latin American Centre for Development Administration (CLAD).

Kliksberg, B. (ed.) (1997): Pobreza. Un tema impostergable. Nuevas respuestas a nivel mundial, Mexico City, Fondo de Cultura Económica (FCE).

Knack, S. and P. Keefer (1997): Does social capital have an economic payoff? A cross-country investigation, Quarterly Journal of Economics, vol. CXII, No. 4, Cambridge, Massachusetts, The MIT Press.

La Porta, R., F. López de Silanes, A. Shleifer and R. Vishny (1997): Trust in large organizations, The
American Economic Review, vol. 87, No. 2, Nashville, Tennessee, American Economic Association.

Levi, M. (1996): Social and unsocial capital: A review essay of Robert Putnam's "Making democracy work", Politics \& Society, vol. 24, No. 1, Los Altos, California, March.

Machado, G. and N. Freites (1994): Experiencias exitosas de gestión social en Lara, in B. Kliksberg (ed.), El desarrollo humano en Venezuela, Caracas, Editorial Monte Avila.

Morin, E. (1991): Un noveau commencement, Paris, Editions du Seuil.

Moser, C. (1998): The asset vulnerability framework: reassessing urban poverty reduction strategies, World Development, vol. 26, No. 1, Oxford, U.K., Pergamon Press.

Navarro, Z. (1998): La democracia afirmativa y el desarrollo redistributivo: el caso del presupuesto participativo en Porto Alegre, Brasil (1989-1998), paper presented at the Seminar on Social Programmes, Poverty and Citizen Participation, Cartagena, Colombia, IDB.

Narayan, D. and L. Pritchett (1997): Cents and Sociability. Household Income and Social Capital in Rural Tanzania, Washington, D.C., World Bank.

Newton, K. (1997): Social capital and democracy, American Behavioral Scientist, vol. 40, No. 5, Princeton, New Jersey, March-April.

Prigogine, I. (1993): ¿Tan sólo una ilusión? Una exploración del caos al orden, Barcelona, Spain, Tusquets Editores.

Putnam, R. (1994): Para hacer que la democracia funcione, Caracas, Editorial Galac.

Rupp, J. C. (1997): Rethinking cultural and economic capital. Reworking class, New York, Cornell University Press.

Sanders J. M. and V. Nee (1996): Immigrant self-employment: The family as social capital and the value of human capital, American Sociological Review, vol. 61, No. 2, Washington, D.C., American Sociological Association.

Sen, A. (1997a): Economics, business principles and moral sentiments, The Journal of the Society for Business Ethics, vol. 7, No. 3, Chicago, Illinois, Loyola University, July.

(1997b): Teoría del desarrollo a principios del siglo XXI, in L. Emmerij and J. Núñez del Arco (eds.), Economic and Social development into the XXI Century, Washington, D.C., IDB.

Serageldin, I. (1998): The Initiative on Defining, Monitoring and Measuring Social Capital: Overview and Program Description, Social Capital Initiative working paper, No. 1, Washington, D.C., World Bank. 
Stiglitz, J. (1998): Más instrumentos y metas más amplias: desde Washington hasta Santiago, Washington, D.C., World Bank.

Teachman, J. D., K. Paasch and K. Carver (1997): Social capital and the generation of human capital, Social Forces, vol. 75, No. 4, Chapel Hill, North Carolina, University of North Carolina, June.

Touraine, A. (1997): Por una nueva política social, El País, Montevideo, 4 August.

UNDP (1998a): Desarrollo humano en Chile 1998, Santiago, Chile.

-(1998b): Human Development Report 1998, Oxford, U.K., Oxford University Press.

UNESCO (1996): Nuestra diversidad creativa, report of the World Commission on Culture and Development, Paris.
Wall, E., G. Ferrazzi and F. Schryer (1998): Getting the goods on social capital, Rural Sociology, vol. 63, No. 2, Pennsylvania, The Pennsylvania University.

Wilson, J. (1994): Los valores familiares y el papel de la mujer, Facetas, No. 1, Washington, D.C.

Wolfensohn, J. D. (1996): El gasto social es clave, Clarín, Buenos Aires, 26 February.

Youniss, J., J. A. McLellan and M. Yates (1997): What we know about engendering civic identity, American Behavioral Scientist, Princeton, New Jersey, March-April.

Zapata, A. V. (1996): Entrevista a Michel Azcueta, in Sociedad y poder local. La Comunidad de Villa El Salvador 1971-1996, Lima, Centre for Development Research and Promotion (DESCO). 